\title{
LIFE CYCLE ASSESSMENT OF THE PRODUCTION CHAIN OF OIL-RICH BIO- MASS TO GENERATE BTL AVIATION FUEL DERIVED FROM MICRAOALGAE
}

\author{
(C) 2014 M. Gehrer, H. Seyfried, S. Staudacher
}

\author{
Institute of Aircraft Propulsion Systems (ILA) University of Stuttgart, Germany
}

\begin{abstract}
Considerable efforts are made to generate drop-in aviation fuels from microalgae to avoid competition with food production. Synthetic biofuel from oil-rich biomass is produced along four process lines: cultivation, harvest, extraction of raw material and conversion to fuel. This study deals with the life cycle assessment of fuel obtained from cultivation of the fresh water alga Auxenochlorella protothecoides and concentrates on the cultivation in open ponds as well as the harvesting steps preconcentration, electroporation and dewatering. Energy balance and environmental impact is analysed using $\mathrm{GaBi}$ software and data base. The main goal is to identify those factors or processes exerting the strongest impact, either environmentally or from the point of view of the energy balance. Production of one kilogram of dry oil-rich algal biomass ( $\mathrm{kg} \mathrm{DM}$ ) consumes $118.56 \mathrm{MJ}$ of primary energy. The primary energy demand is apportioned as follows: $71.7 \%$ during proliferation in Erlenmeyer flags and bubble columns, $15.5 \%$ by cultivation in raceway ponds and $12.8 \%$ in preconcentration, electroporation and dewatering. This converts into a net energy ratio (NER) of 0.266 and a $\mathrm{CO}_{2}$-equivalent of $6.45 \mathrm{~kg} \mathrm{CO}$ per $\mathrm{kg}$ DM. These values are disadvantageous when compared to kerosene $\left(N E R=0.867,0.384 \mathrm{~kg} \mathrm{CO}_{2} \mathrm{per} \mathrm{kg}\right.$ kerosene). Production can be optimized using process energy from regenerative sources such as hydroelectric power $\left(N E R=0.545,1.27 \mathrm{CO}_{2}\right.$ per $\left.\mathrm{kg} \mathrm{DM}\right)$. In this case total primary energy input must be corrected for the portion of renewable sources resulting in a $N E R_{\text {corr }}$ of 3.04. $\mathrm{CO}_{2}$-equivalents per $\mathrm{kg} \mathrm{DM}$ remain unfavourably high as compared to kerosene; the main driver responsible for this discrepancy is the usage of freshwater and fertilizer.
\end{abstract}

Biofuel, microalgae, auxenochlorella protothecoides, energy balance, electroporation, renewable energy.

NOMENCLATURE

$\begin{array}{ll}\mathrm{BtL} & \text { Biomass-to-liquid } \\ \mathrm{CtL} & \text { Coal-to-liquid } \\ C_{\mathrm{B}} & \text { Total suspended solids } \\ \mathrm{CO}_{2} & \text { Carbon dioxide } \\ \mathrm{GtL} & \text { Gas-to-liquid } \\ \mathrm{Hu} & \text { Calorific value } \\ \mathrm{HVO} & \text { Hydrogenated vegetable oil } \\ \text { corr } & \text { corrected } \\ N E R & \text { Net energy ration } \\ \mathrm{DM} & \text { Dry matter } \\ \mathrm{N} & \text { Nitrogen } \\ \mathrm{P} & \text { Phosphorous }\end{array}$

\section{INTRODUCTION}

Biofuels currently are mostly produced from terrestrial plants containing oil, starch or sugar such as soy beans, raps, corn and sunflower seeds or palm oil. Present technologies are almost fully developed but cultivation involves substantial land use and needs fertile soils 5. Hence, considerable efforts are made to generate biofuels (including biodiesel) from other sources to avoid competition with food production. This is especially true for aviation fuels. Microalgae turned out to be an almost ideal alternative as they contain significantly higher concentrations of oil and carbohydrates, possess high to very high photosynthetic activity and re- quire comparatively less land use than terrestrial plants 22. Yield from microalgae with oil concentrations about $30 \%$ per dry weight is 9 to 300 times higher than that of conventional crops 5 .

From an economical point of view it is most desirable that a biofuel may be used without any alterations to the aircraft and the engines (drop-in fuels). Possible processes to produce drop-in fuels focus on FischerTropsch synthesis applied to coal, gas or biomass ( $\mathrm{CtL}, \mathrm{GtL}, \mathrm{BtL})$ and hydration of vegetable oil (HVO). Raw material is converted to carbohydrates possessing almost identical chemical properties when compared to kerosene $(7,8)$. BtL and HVO from microalgae are considered an environmentally sensible alternative with high potential to replace fossil resources.

\section{PRINCIPLES OF BIOFUEL PRO- DUCTION FROM MICROALGAE}

Biofuel is produced along four process lines: cultivation, harvest, extraction of raw material and conversion to fuel. Cultivation is managed in open or closed systems $(1,3$, 5). Open systems are simple, cost-efficient and mainly composed of concrete ponds (raceway ponds) where the alga suspension is 
driven by paddle wheels 1 . However, such systems are susceptible to contamination and changes in the dissolved load as a result from evaporation or precipitation 1 . Closed systems (photobioreactors) are complex, require intense maintenance and demand much more energy than open systems $(5,15)$. Both systems need carefully adjusted quantities of nutrients $(\mathrm{N}, \mathrm{P}), \mathrm{CO}_{2}$ and light. Harvesting methods (centrifugation, flotation, filtration, and flocculation) depend on species composition of the alga suspension and cell sizes 1 . After compaction the remaining intracellular water must be extracted by mechanical or chemical methods. In the final step lipids are converted to biodiesel or HVO and oil-rich biomass is transformed into BtL 6. Our research project concentrates on the life cycle assessment of synthetic fuel obtained from cultivation of a fresh water alga (Auxenochlorella protothecoides) particularly well suited for biofuel production as a result from its very high photosynthetic activity and oil content. Energy balance and environmental impact is analysed using GaBi software and data base 19. This paper presents results from the life cycle assessment of the cultivation, harvest and extraction paths of the production chain leading to oil-rich biomass.

\section{LIFE CYLE ASSESSMENT}

Input, output and environmental impact are quantified following the procedure defined in DIN EN ISO 14044, i.e. study goal and scope, inventory analysis, impact and interpretation 9. On this background it is possible to clearly identify those factors or processes exerting the strongest impact, either environmentally or from the point of view of the energy balance. Industrial-size plants for the production of biofuel from microalgae do not exist until today but a wealth of data is already available from laboratory and pilot plants $(2,4)$.

Within the scope of this study the following assumptions and parameters are made and set:

- the functional unit of life cycle assessment is $1 \mathrm{~kg}$ dry matter $(\mathrm{kg} \mathrm{DM})$
- biomass production and extraction is performed in Europe

- evaporation totals $101 \mathrm{~m}^{-2} \mathrm{~d}$ and thus does not require fertilizer compensation or dilution 1

- $1 \mathrm{~kg}$ DM fixes $1.8 \mathrm{~kg} \mathrm{CO}_{2}(5,21)$

- concentration of suspended organic solids $\left(C_{\mathrm{B}}\right)$ is constant throughout the cultivation process $\left(C_{\mathrm{B}}=1.3 \mathrm{~g} / \mathrm{l}\right)$

- residual water from the harvesting step(s) can be recycled without further treatment; excess water enters the waste water balance

- the calorific value $\left(H_{\mathrm{u}}\right)$ of $1 \mathrm{~kg} \mathrm{DM}$ is 31.55 MJ 16

- stepwise cultivation following the initial laboratory stage produces less contamination than continuous cultivation 3

- facilities and in particular cost and environmental impact related to their production do not enter the life cycle assessment. This is common practice in assessments of long-lived and highly productive assets on the reason that the emissions caused by the working unit surpass those of facility manufacturing by several orders of magnitude 19.

\section{INVENTORY ANALYSIS OF PRO- DUCTION OF OIL-RICH BIOMASS}

\subsection{Cultivation}

Cultivation is a stepwise process chain (Fig. 1) starting with breeding under controlled laboratory conditions, proliferation in Erlenmeyer flags and further alga enrichment in bubble columns followed by raceway ponds of increasing capacity. Proliferation in Erlenmeyer flags takes 7 days. Further enrichment takes 10 days per step; lipid enrichment in the last step takes 15 days. Each cultivation unit must be inoculated with fresh alga suspension to avoid contamination with other algae or undesired organisms 4 . The inoculation volume amounts to $10-15 \%$ of the volume of the cultivation unit; the rest is fresh water. Preceding units must be multiplied according to the inoculation volume needed in the following unit (Fig. 1). 


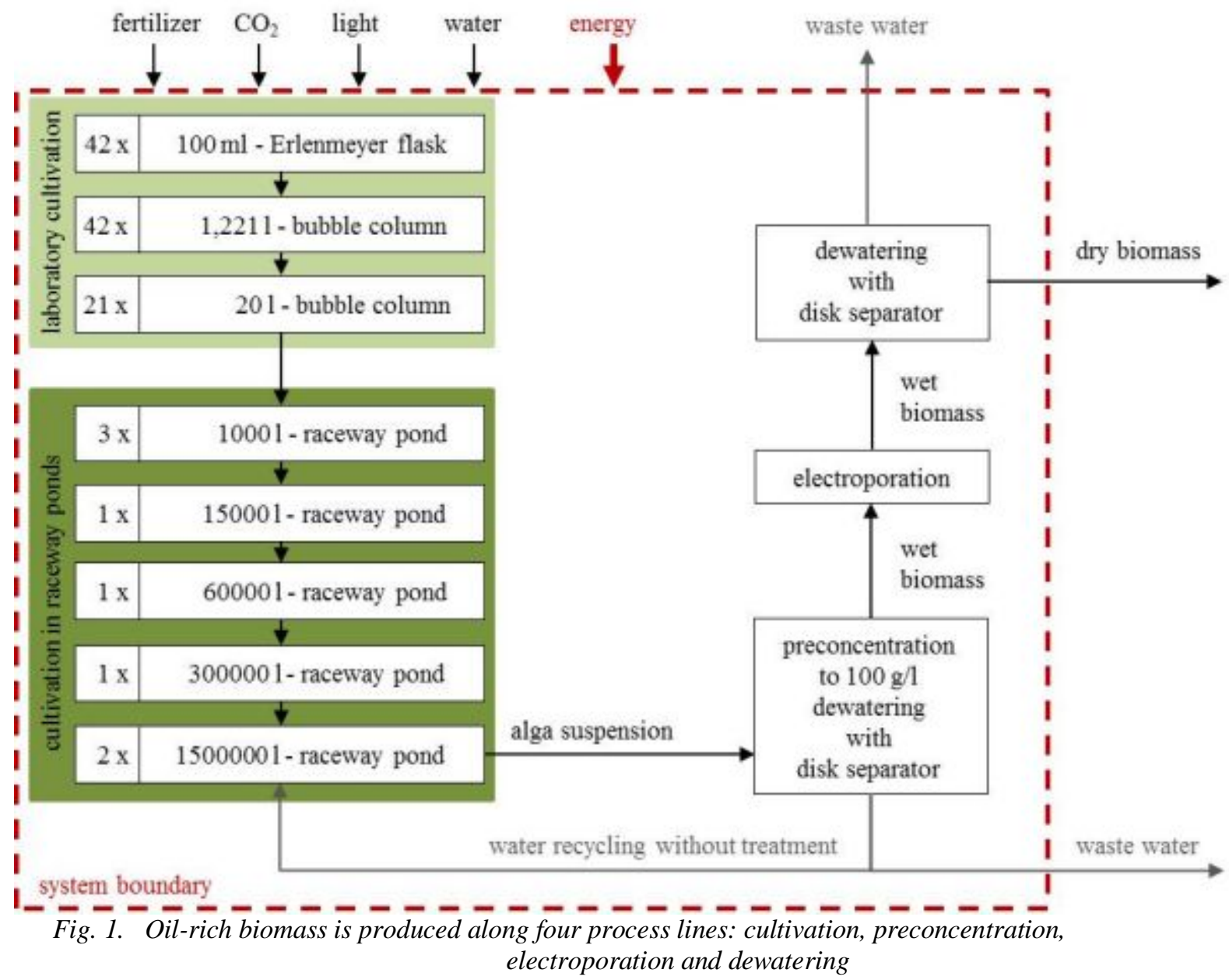

A typical path through the production steps requires the following quantities:

- two 1.2211 bubble columns replenish one 201 bubble column

- seven 201 bubble columns replenish one 10001 raceway pond

- three 10001 raceway pond replenish one 150001 raceway pond

- further steps are explained in Fig. 2. The last step (lipid enrichment) occurs in a 15000001 raceway pond. In comparison the foregoing steps it takes 15 days; thus, to obtain a harvest every 10 days two of these large ponds are needed. The final output totals 1950 kg DM per pond.

For optimal growing Auxenochlorella protothecoides requires accurate doses (Tab. 1) of nitrogen $(\mathrm{N})$, phosphorus $(\mathrm{P})$, magnesium $(\mathrm{Mg})$, iron $(\mathrm{Fe})$ and calcium $(\mathrm{Ca})$. Biomass enrichment works best at a nitrogen concentration of $2 \mathrm{mmol}$ per litre. In the last step, however, this concentration must be reduced to $1 \mathrm{mmol}$ per litre because other- wise algae will not enrich lipids. Constant $\mathrm{pH}$ control to buffer the input of $\mathrm{CO}_{2}$ is maintained with $\mathrm{KH}_{2} \mathrm{PO}_{4}$ (3 mmol per litre) 4 .

Tab. 1. Nutrient concentration in $\mathrm{mmol}^{-1} \mathbf{4}$

\begin{tabular}{lr}
\hline Nutrient & $\mathrm{mmol} \mathrm{l}^{-1}$ \\
\cline { 3 - 3 }$(\mathrm{NH})_{4} 2 \mathrm{HPO}_{4}$ & 2.0 \\
$\mathrm{KH}_{2} \mathrm{PO}_{4}$ & 3.0 \\
$\mathrm{MgSO}_{4} * 7 \mathrm{H}_{2} \mathrm{O}$ & 0.5 \\
$\mathrm{FeSO}^{2} * 7 \mathrm{H}_{2} \mathrm{O}$ & 0.02 \\
$\mathrm{CaCl}_{2} * 2 \mathrm{H}_{2} \mathrm{O}$ & 0.2 \\
\hline
\end{tabular}

The proliferation step in Erlenmeyer flags needs electrical energy for illumination, cooling, aeration, the orbital shaker and cleaning totalling $66 \mathrm{kWh}$ in 7 days for $200 \mathrm{ml}$ alga suspension in two flags. Ensuing cultivation in two 1.221 l bubble columns consumes $377.2 \mathrm{kWh}$ for illumination, air conditioning and injection of $\mathrm{CO}_{2}$. A 201 bubble column expends $353.4 \mathrm{kWh}$ in 10 days. Illumination scales per area while cooling scales per volume $\left(\mathrm{Q} \sim \mathrm{V}^{2 / 3}\right)$. 
Suspension in raceway ponds is kept in circulation by paddle wheels producing a mean of $30 \mathrm{~cm} \mathrm{~s}^{-1}$ consuming $0.016 \mathrm{kWh} \mathrm{m}^{-}$ ${ }^{2} \mathrm{~d}^{-1}(1,3)$. In the last pond (lipid enrichment) circulation requires $0.65 \mathrm{kWh}$ per $\mathrm{kg} \mathrm{DM}$ whereas all previous ponds consume $0.41 \mathrm{kWh}$ per $\mathrm{kg} \mathrm{DM}$. The carbonator injects $2.6 \mathrm{~kg} \mathrm{CO}$ per $75 \mathrm{~m}^{2}$ surface in 10 hours 3 ; per $\mathrm{kg} \mathrm{CO} 20.0222 \mathrm{kWh}$ are needed 17 . It is economically and ecologically favourable to use industrial flue gas from power plants 22 . Excess $\mathrm{CO}_{2}$ via outgassing from the water surface enters the life cycle assessment. Photosynthetic produced oxygen is regarded as an emission. Transferring suspension among raceway ponds with circular pumps yielding $50 \mathrm{~m}^{3} \mathrm{~h}^{-1}$ consumes $9 \mathrm{~kW} \mathrm{14}$. Energetic requirements are summarized in Tab. 2 .

Tab. 2. Process energy of raceway pond in $\mathrm{kWh}$

\begin{tabular}{lr}
\multicolumn{2}{c}{ per kg DM $(\mathbf{1}, \mathbf{1 4}, 17)$} \\
\hline Process step & $\mathrm{kWh}$ per kg DM \\
\hline Paddle wheel & $0.41(0.65)$ \\
$\mathrm{CO}_{2}$-injection & 0.0222 \\
Pumping & 0.138 \\
\hline
\end{tabular}

\subsection{Pretreatment}

The green alga Auxenochlorella protothecoides measures $2-12 \mu \mathrm{m} \mathrm{13}$. As a result from this size distribution it is compulsory to use centrifuges to guarantee an adequate throughput and the desired concentration of $C_{\mathrm{B}}=100 \mathrm{~g} \mathrm{l}^{-1}$. A special disk separator for microalgae providing a throughput of $24 \mathrm{~m}^{3} \mathrm{~h}^{-1}$ possesses $30 \mathrm{~kW}$ effective capacity $(11,20)$.

\subsection{Electroporation}

A common method to accede the cell water is the destruction of membranes by electroporation under high voltage producing holes permeable for water molecules (1012). Until today only pilot plants are functional yielding a throughput of $0.51 \mathrm{~h}^{-1}$ consuming 1.5 MJ per kg DM 10.

\subsection{Dewatering}

Final solid-liquid separation must remove interstitial and intracellular free water to separate the concentrate of oil-rich bio- mass using disk separators from the pretreatment step.

Tab. 3 summarizes energy inputs and operation materials for the complete production chain normalized to $1 \mathrm{~kg} \mathrm{DM}$.

Tab. 3. Energy inputs and operation materials for the complete production chain normalised to $\operatorname{kg} \operatorname{DM}(1,14,17)$

\begin{tabular}{lrr}
\hline Process step & $\begin{array}{r}\text { Amount per } \\
\mathrm{kg} \text { DM }\end{array}$ & Unity \\
\cline { 2 - 2 } Laboratory Cultivation & & \\
Electric energy & 8.578 & $\mathrm{kWh}$ \\
Fertilizer & $2,1 \cdot 10^{-4}$ & $\mathrm{~kg}$ \\
Fresh water & 0.228 & $\mathrm{~kg}$ \\
Raceway ponds & & \\
Electric energy & 0.802 & $\mathrm{kWh}$ \\
Fertilizer & 0.729 & $\mathrm{~kg}$ \\
Fresh water & 2.6 & $\mathrm{~kg}$ \\
CO 2 & 564.4 & $\mathrm{~kg}$ \\
Preconcentration & & \\
Electric energy & 1.1 & $\mathrm{kWh}$ \\
Electroporation & & \\
Electric energy & 0.417 & $\mathrm{kWh}$ \\
Dewatering & & \\
Electric energy & 0.0125 & $\mathrm{kWh}$ \\
\hline
\end{tabular}

\section{RESULTS}

Fig. 2 details the distribution of the primary energy demand among the different production steps leading to the reference mass $(1 \mathrm{~kg} \mathrm{DM})$. The cumulative primary energy demand for the entire process chain is $118.56 \mathrm{MJ}$ per $\mathrm{kg} \mathrm{DM}$. The primary energy demand is apportioned as follows: $71.7 \%$ during proliferation in Erlenmeyer flags and bubble columns, $15.5 \%$ by cultivation in raceway ponds and $12.8 \%$ in harvesting steps (pretreatment, electroporation, dewatering). It is obvious that the high primary energy demand of the laboratory stage results from energy consuming processes such as cooling $(82.8 \%)$ and illumination $(10.5 \%)$. The primary energy demand for operation material is under $1 \%$ o. In a balance of the complete production chain process energy again is responsible for the bulk of primary energy demand $(91.2 \%)$. Fertilizer and freshwater account for $8.8 \%$. 


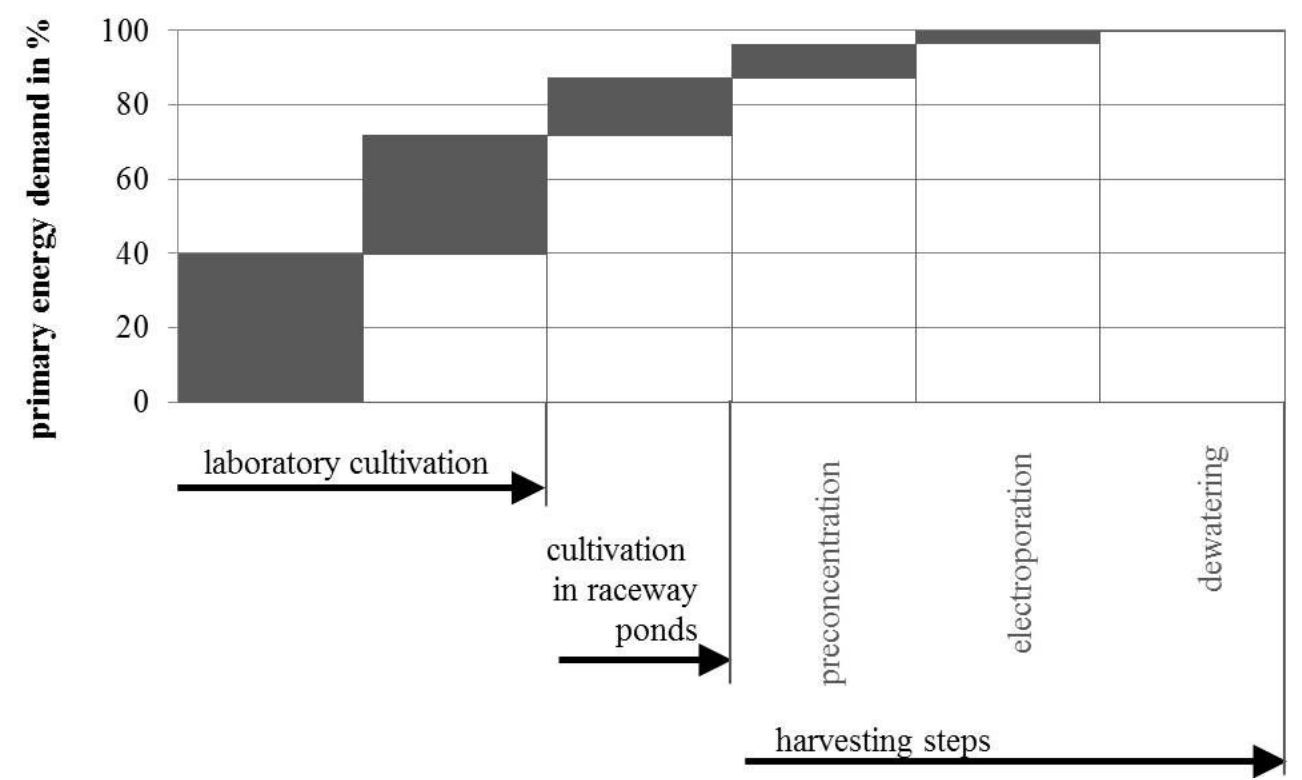

Fig. 2. Distribution of the cumulative primary energy to produce $1 \mathrm{~kg} \mathrm{DM}$

Modelling the production of the reference mass (1 kg DM) with GaBi (Fig. 3) resulted in a total primary energy demand of 118.56 MJ distributed between process energy (39.27 MJ) and operational material $(10.4 \mathrm{MJ}$ related to $567.957 \mathrm{~kg}) . \quad 102.8 \mathrm{MJ}$ out of the sum of $118.56 \mathrm{MJ}$ are from nonrenewable sources and $15.76 \mathrm{MJ}$ are from regenerative input. The non-renewable portion splits into process energy $(90.2 \%)$ and operational material $(9.8 \%)$. Process energy enters modelling as European energy mix requiring $2.75 \mathrm{MJ}$ primary energy to create an output of $1 \mathrm{MJ}$. Out of these $2.75 \mathrm{MJ}$ $2.36 \mathrm{MJ}$ correspond to non-renewable and $0.39 \mathrm{MJ}$ to renewable sources 19.

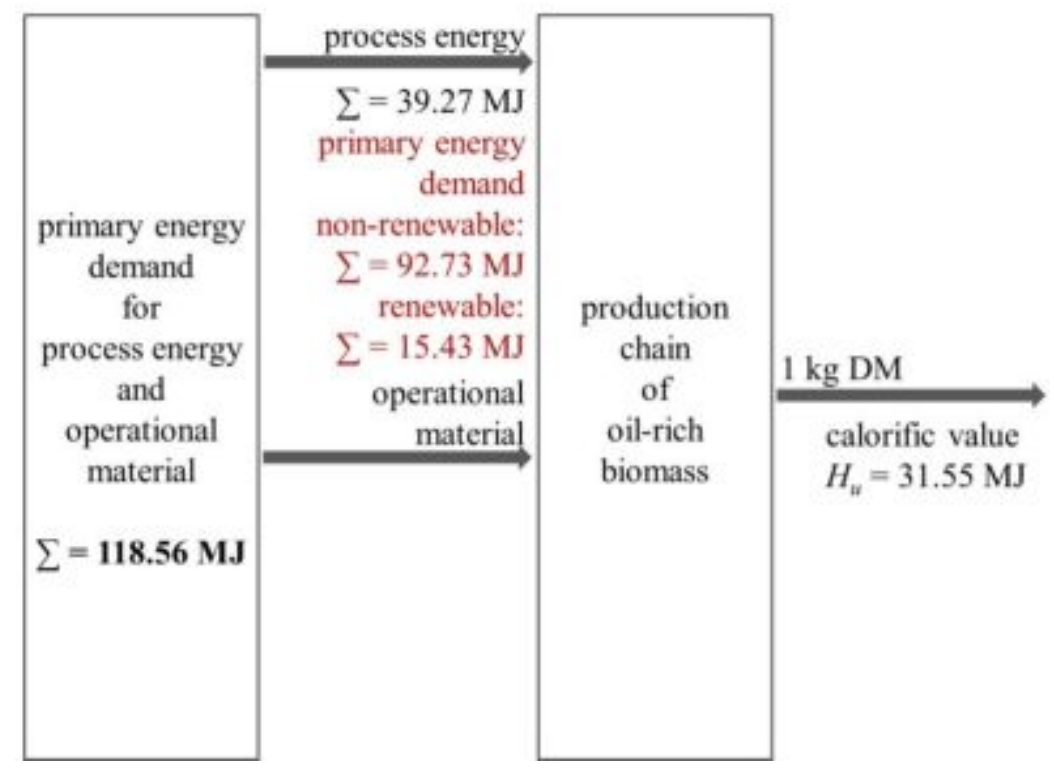

Fig. 3. Composition of the primary energy consumption to produce $1 \mathrm{~kg}$ DM algal biomass

Relations between the type of process energy and the corresponding portions of non-renewable/renewable sources of energy are shown in Fig. 4. Photovoltaic energy production rises the cumulative primary energy demand from $118.56 \mathrm{MJ}$ to $315.6 \mathrm{MJ}$ but the split into $18.98 \mathrm{MJ}$ non-renewable and 296.66 MJ renewable ultimately entails a positive balance. Wind and hydroelectric energy supply reduce primary energy demand to $110.48 \mathrm{MJ}$ and $57.91 \mathrm{MJ}$, respectively. In these cases the non-renewable portion is even below $2 \%$. 


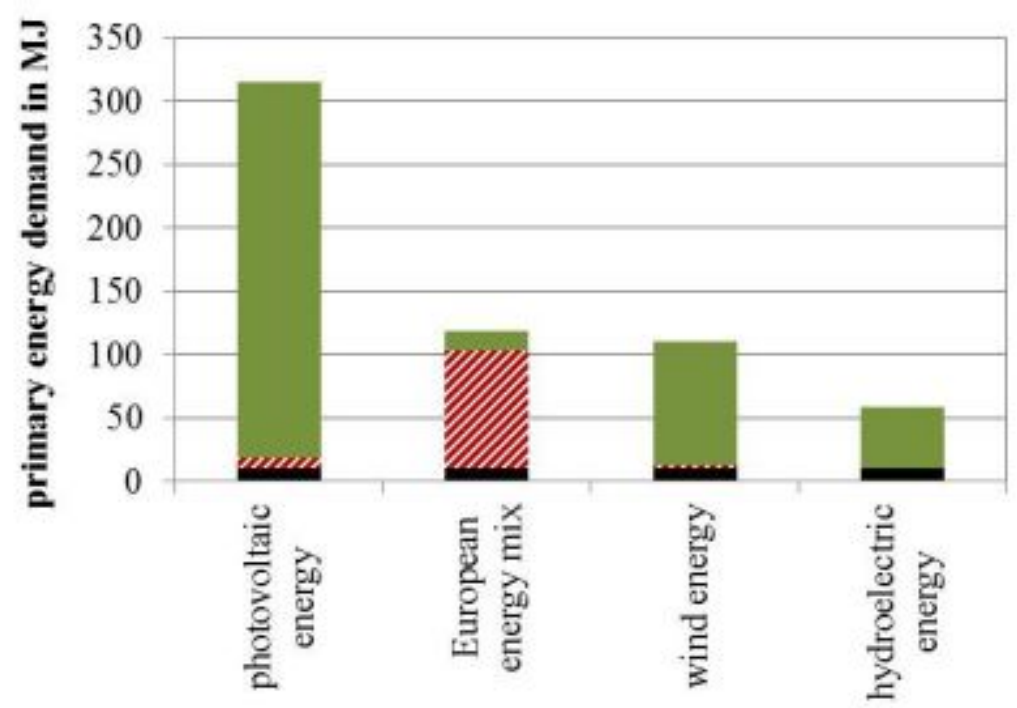

process energy
renewable

\% process energy nonrenewable

operational material renewable and nonrenewable

Fig. 4. Primary energy consumption in MJ per kg DM depending on different sources of electric energy

The net energy ratio $(N E R)$ turned out to be a useful term when largely differing products linked with different processes are to be compared. The ratio compares the calorific value $\left(H_{\mathrm{u}}\right)$ of a product with total primary energy demand involved in production 16.

$$
N E R=\frac{\text { calorific value }}{\text { total primary energy demand }} \text {. }
$$

Consequently, a process is economically reasonable when $N E R$ is $>1$ because less energy is required for production than stored in product. For the case studied here the NER related to the production of 1 $\mathrm{kg} \mathrm{DM}$ is $0.266\left(H_{\mathrm{u}}=31.55 \mathrm{MJ}\right.$, cumulative demand $=118.56 \mathrm{MJ}$ ). This is unfavourable per se and it is even more so when compared to the NER of kerosene (0.867) 19. Using wind energy rises the NER to 0.286; water energy increases NER to 0.545 but photovoltaic energy sources result in very low values $(\mathrm{NER}=0.1)$. However, as this balance integrates both non-renewable and renewable sources of primary energy demand a correction must be applied to the renewable portion because it is supposed to be environmentally neutral and does not imply the use of fossil resources. Accordingly, $N E R_{\text {corr }}$ is calculated as the relation between $H_{\mathrm{u}}$ and the nonrenewable portion of the primary energy demand 18. In Tab. $4 N E R$ and $N E R_{\text {corr }}$ of the process chain leading to algal biomass production are plotted against different sources of energy and compared to kerosene.

$$
N E R_{\text {corr }}=\frac{\text { calorific value }}{\text { non-renewable primary energy demand }} \text {. }
$$

Tab. 4 - NER and $N E R_{\text {corr }}$ of the process chain leading to algal biomass production for different sources of electric energy and for kerosene

\begin{tabular}{lrrr}
\hline Sources of electric energy & & $N E R$ & $N E R_{\text {corr }}$ \\
European energy mix & 0.266 & & 0.307 \\
Photovoltaic energy & 0.1 & & 1.66 \\
Wind energy & 0.286 & 2.66 \\
Hydroelectric energy & 0.545 & 3.04 \\
for comparison & & \\
Kerosene & 0.867 & 0.869 \\
\hline
\end{tabular}

It is most remarkable that even the initial biomass production path of biofuel production from microalgae is economically only reasonable when renewable sources of energy are used. Expectedly, $\mathrm{CO}_{2-}$ equivalents also are well below the reference value of kerosene: $6.45 \mathrm{~kg} \mathrm{CO}$-equivalents per $\mathrm{kg} \mathrm{DM}$ as compared to $0.384 \mathrm{~kg} \mathrm{CO}_{2}$ equivalents per $\mathrm{kg}$ kerosene 19 . If process energy is derived from renewable sources $\mathrm{CO}_{2}$-equivalents per $\mathrm{kg} \mathrm{DM}$ reduce to 1.76 (photovoltaic), 1.33 (wind) and 1.27 (water). Even so the values are still higher than in the case of kerosene; the main driver responsible for this discrepancy is the usage of freshwater and fertilizer.

\section{CONCLUSION}

This study quantitatively demonstrates that production of one kilogram of algal 
biomass from the fresh water microalga $A u x$ enochlorella protothecoides consumes 118.56 MJ of primary energy. This corresponds to $91.2 \%$ of the total process energy; the remaining $8.8 \%$ relate to use of fertilizers and fresh water. Employing European electrical energy mix results in a $\mathrm{CO}_{2-}$ equivalent of $6.45 \mathrm{~kg} \mathrm{CO}$ per $\mathrm{kg} \mathrm{DM}$ and delivers a $N E R$ of 0.266 . This value is adverse to that of kerosene $(N E R=0.867)$. If process energy originates from regenerative sources the $\mathrm{CO} 2$ equivalent drops to 1.27 of $\mathrm{CO}_{2}$ per $\mathrm{kg} \mathrm{DM}$ and the NER rises to 0.545 .
$N E R_{\text {corr }}$ considerably improves from 0.545 to 3.04 when total primary energy input is corrected for the portion of renewable sources. Hence, it becomes clear that generation of algal biomass for synthetic biofuel production is economically and environmentally disadvantageous unless primary energy input stems from renewable sources. In particular, this implies that independently from all other processes of the production line (e.g., refining, transport) all processes and operational materials must be strictly designed to the principles of minimal release of $\mathrm{CO}_{2}$.

\section{References}

1. Becker E.W. Microalgae: Biotechnology and Microbiology. New York: Cambridge University Press, 2008. 519 p.

2. Ben-Amotz A. Bio-fuel and CO2 Capture by Algae. Seambiotic Ltd., 2008.

3. Borowitzka M.A. Algal Culturing Techniques. Section no. 14. Culturing microalgae in outdoor ponds. $2005.596 \mathrm{p}$.

4. Büchle C. Konstruktion und Aufbau eines Photobioreaktors zur onlineÜberwachung der Produktivität von Algen und Erfassung der Produktivitätsparameter von Auxenochlorella protothecoides. Diploma Thesis, Institute of Botany, University of Stuttgart, 2013.

5. Chisti Y. Biodiesel from Microalgae // Biotechnology Advances. 2007. V. 25, no. 3. P. 294-306.

6. Cooney M. et al. Extraction of Bio-oils from Microalgae // Separation \& Purification Reviews. 2011. V. 38, no. 4. P. 291-325.

7. Daggett D. et al. Alternative Fuels and Their Potential Impact on Aviation. ICAS2006-5.8.2, Hamburg, Germany, 2006.

8. Daggett D. et al. Alternative Fuels for Use in Commercial Aircraft. ISABE-20071196, Peking, China, 2007.

9. Din En ISO 14044 Umweltmanagement - Ökobilanz-Anforderungen und Anleitung. Deutsches Institut für Normung e.V., 2006.

10. Frey W. et al. Konditionierung von Mikroalgen mit gepulsten elektrischen Feldern für die energetische Nutzung. Sustainable BioEnconomy, 2011.

11. Gea westfalia separator group: Separation Technology for Algae Production. GEA Mechanical Equipment $\mathrm{GmbH}$, Deutschland, 2012.
12. Göttel M. et al. Influence of Pulsed Electric Field (PEF) Treatment on the Extraction of Lipids from Microalgae Auxenochlorella protothecoides // IEEE International Conference on Plasma Science, 2011.

13. Graham L.E. et al. Algae. New Jersey: Prentice-Hall Inc., 2000. 640 p.

14. Grundfos: Pumpenhandbuch, 2004.

15. International air transport association: Report on Alternative Fuels. www.iata.org, 2008.

16. Jorquera O. et al. Comparative Energy Life-Cycle Analyses of Microalgal Biomass Production in Open Ponds and Photobioreactors // Bioresource Technology. 2010. V. 101, no. 4. P. 1406-1413.

17. Kadam K.L. Environmental Implications of Power Generation via CoalMicroalgae Cofiring // Energy. 2002. V. 27, no. 10. P. 905-922.

18. Manish S. et al. Sustainable Analysis of Renewables for Climate Change Mitigation // Energy for Sustainable Development. 2006. V. 10, no. 4. P. 25-36.

19. PE International: Gabi Software: manual, 2012.

20. Pieralisi: Vertikale Tellerseparatoren. StampaNova, Jesi (AN), Italy, 2000.

21. Connelly R. et al. Second-Generation Biofuel from High-Efficiency Algal-Derived Biocrude // Bioenergy Research: Advances and Applications. 2008. P. 153-170.

22. Sheehan J. et al. A Look back at the U.S. Department of Energy's and Aquatic Species Program: Biodiesel from Algae. Close-Out Report, Golden, Colorado, USA: National Renewable Energy Laboratory, 1998. 


\title{
About the authors
}

Gehrer Manuela, Research Associate, Institute of planetology, University of Stuttgart, Germany. Area of Research: aircraft engines, biofuels, renewable energy.

Seyfried Hartmut, Doctor of Science, Professore, Institute of planetology, University of Stuttgart, Germany. E-mail: stephan.staudacher@ ila.uni-stuttgart.de. Area of

Research: aircraft engines, biofuels, renewable energy.

Staudacher Stephan, Doctor of Science, Professore, Institute of Aircraft Propulsion Systems (ILA), University of Stuttgart, Germany. E-mail: stephan.staudacher @ila.uni-stuttgart. de. Area of Research: aircraft engines, biofuels, renewable energy.

\section{ОЦЕНКА ПРОИЗВОДСТВЕННОЙ ЦЕПОЧКИ БИОМАСС ИЗ НАСЫЩЕННЫХ ЖИРАМИ МИКРОВОДОРОСЛЕЙ ДЛЯ ПОЛУЧЕНИЯ АВИАЦИОННОГО БИОТОПЛИВА}

\author{
(C) 2014 М. Герер, Х. Сейфрид, С. Штаудахер
}

Институт авиационных двигателей Университета Штутгарта, Германия

\begin{abstract}
В настоящее время прилагаются значительные усилия для создания авиационного биотоплива из микроводорослей, абсолютно взаимозаменяемого с традиционным видами авиационных топлив. Эти действия осуществляются, чтобы не использовать для этих целей продукты питания. Синтетическое биотопливо из биомассы с высоким содержание жировых компонентов изготавливается по следующей технологической цепочке: выращивание культур, сбор урожая, извлечение сырьевой базы, переработка её в топливо. Это исследование посвящено технологическому циклу производства топлива, полученного культивированием водорослей Auxenochlorella protothecoides в пресной воде и сосредоточено на культивировании культуры в открытых водоёмах, а также на последовательности действий в ходе сбора сырья, таких как: предварительное обогащение, электропорация и обезвоживание. Топливноэнергетический баланс и воздействие на окружающую среду анализируется при помощи программного пакета $\mathrm{GaBi}$ и базы данных. Главная цель работы заключается в выявлении факторов и процессов, оказывающих наибольшее влияние как на экологическую составляющую, так и на энергетический баланс. Так для производства одного килограмма обезвоженной биомассы из водорослей с высоким содержанием жировых компонентов (кг сухого вещества) требуется затратить 118,56 МДж энергии. Потребление энергии распределяется следующим образом: 71,7\% расходуется в процессе роста микроорганизмов к колбах Эрленмейера и в барботирующих ферментёрах, 15,5\% используется для выращивания в каналах водоёма и 12,8\% потребляется для предварительного обогащения, электропорации и обезвоживания. Преобразуя величины в соотношение суммарной энергии (NER), получили значение 0,266 , а в $\mathrm{CO}_{2}$ эквиваленте получили 6,45 кг $\mathrm{CO}_{2}$ на кг сухого вещества. Полученные значения хуже аналогичных зависимостей для керосина $\left(\mathrm{NER}=0,867 ; 0,384\right.$ кг $\mathrm{CO}_{2}$ на кг керосина). Производство может быть оптимизировано благодаря использованию требуемой энергии из возобновляемых источников, таких, например, как гидроэлектростанции (NER = 0,545; 1,27 кг $\mathrm{CO}_{2}$ на кг сухого вещества). В этом случае суммарная величина энергии на входе должна быть скорректирована при использовании возобновляемых источников, приводящих NER к 3,04. Тем не менее, оценка $\mathrm{CO}_{2}$ эквивалента на килограмм сухого вещества остаётся по - прежнему неблагоприятно высокой в сравнении с керосином. Основной причиной столь существенного различия является использование чистой лабораторной воды и удобрений.
\end{abstract}

Биотопливо, микроводоросли, топливно-энергетический баланс, электропорация, возобновляемая энергия.

\section{Информация об авторах}

Герер Мануэла, научный сотрудник, Институт авиационных двигателей (ILA), Университет Штутгарта, Германия. Область научных интересов: авиационные двигатели, биотопливо, возобновляемая энергия.

Сейфрид Хартмут, доктор наук, профессор, Институт планетологии, 
Университет Штутгарта, Германия. двигателей (ILA), Университет Область научных интересов: авиационные Штутгарта, Германия. E-mail: stephдвигатели, биотопливо, возобновляемая an.staudacher@ila.uni-stuttgart.de. Область энергия.

научных интересов: авиационные

Штаудахер Стефан, доктор наук, двигатели, биотопливо, возобновляемая профессор, Институт авиационных энергия. 